\title{
AGRICULTURAL LANDS, STRATEGIC INVESTMENT IN ROMANIA'S SUSTAINABLE DEVELOPMENT
}

\author{
Mancia Mircea-Sebastian ${ }^{340}$ \\ Mancia Aurora ${ }^{341}$
}

https://doi.org/10.31410/itema.2018.1002

\begin{abstract}
The European land market is undergoing continuous transformation. Every European state is trying to protect its capital, this vital resource that may depend at one point even on the sovereignty of a state. Sustainable development of a country means protecting the environment, water, air, soil, biodiversity in the context of today's explosive economic growth. Romania is among the European countries with fertile, productive land. Local agriculture must develop production models where land management does not lead to overexploitation until depletion. The exponential growth of the earth's population leads to a growing demand for food, agricultural products. Agricultural land represents a limited resource that ensures food security. One of the main objectives of sustainable development-considering the geopolitical areas and European policy for protecting specific areas - is to put to good use the economic potential of the regions in an increasingly globalized economy.
\end{abstract}

Keywords: sustainable development, land market, agricultural land, overexploitation, global economy

\section{INTRODUCTION}

$\mathrm{T}$ The contemporary international environment, including the European one, is in a continuous change. This environment also includes the land market, vital resource and strategic capital for each state. We are linked to the physical-geographic environment, to the concrete space with resources and natural resources, with the economic elements obtained through human intervention, to regions of maximum economic interest and their impact on the environment.

\section{CONTENT}

Romania is one of the leading countries of Europe regarding the fertility of the earth, but also as arable land per head of the population. Global policies and strategies for preserving and using primary resources also include Romania.

On Terra, the total arable area per head of the population is estimated at 1.5 ha. Agriculture is a source of food and an essential engine for economic growth.

The food issue on a planet with such an exponential growth of the population $(7.65$ billion inhabitants in September 2018) is a continual challenge and is intrinsically linked to:

\footnotetext{
${ }^{340}$ University of Oradea, Faculty of Construction, Cadastre and Architecture, Oradea, 4 B.St. Delavrancea, 410058, Bihor, Romania

341 University of Oradea, Faculty of Construction, Cadastre and Architecture, Oradea, 4 B.St. Delavrancea, 410058, Bihor, Romania
} 
- $\quad$ food security from a qualitative and quantitative point of view;

- $\quad$ exploiting existing potential;

- $\quad$ the protection of the environment and natural resources;

- economic models with the highest production without depleting the fertile land through overexploitation.

The land market of Romania undergoes major changes, but a law that protects this valuable resource (although it was initiated in 2014) has not yet been completed.

According to a study by the Transnational Institute for the European Union's Agriculture Committee, more and more agricultural land in Eastern Europe is being purchased by foreign citizens outside the European Union, but also from the European Union.

Romania has liberalized the land market on 1 January 2014.

Romania's agricultural area is $55.9 \%$ of the country's total area and 7.36\% of Europe's surface area. According to data provided by the National Institute of Statistics, out of 13.9 million hectares of agricultural land, 8.2 million ha are arable land. According to the European Union study, about 5.3 million ha of land belong to foreigners, i.e. around $40 \%$, out of which $30 \%$ are foreigners from European Union and 10\% citizens resident in non-EU.

More and more European countries choose to protect their agricultural lands, and they impose restrictions on their purchase by foreign citizens. In 2017, Serbia adopted a project whereby foreign citizens who want to buy agricultural land in this country have to live here for at least 10 years before buying land. (Bloosberg and Agerpress). The French President Emmanuel Macron declared in the summer of 2018 that "France's agricultural land is a strategic investment on which our sovereignty depends, so we cannot let hundreds of hectares be bought by foreign powers." In Hungary, there is also a law limiting the sale of agricultural land to foreign citizens.

Sustainable development means exploitation, but also protecting the country's land potential, protecting the environment: soil, water, air, in the context of the food demand increase and current explosive economic growth.

Figure 1: Average of agricultural land / inhabitant

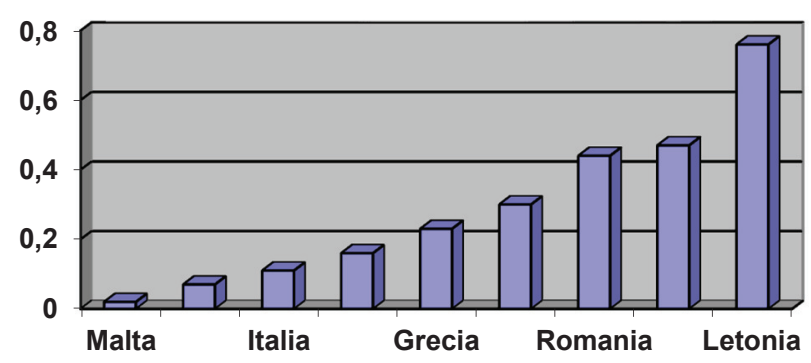

口Average

(Source: World Bank Development Indicators, 2015)

Over the past 10 years, Romania has become a pole of attraction for foreign investors. One of the most active markets for agricultural land transactions is the western area of Romania, followed by Bărăgan (table 1). 
Table 1: Agricultural land values, 2014-2017 (source: LAPAR)

\begin{tabular}{|l|c|r|r|r|r|}
\hline County & $\mathbf{2 0 1 4}$ & $\mathbf{2 0 1 5}$ & $\mathbf{2 0 1 6}$ & \multicolumn{1}{c|}{$\mathbf{2 0 1 7}$} & \multicolumn{1}{c|}{$\mathbf{2 0 1 8}$} \\
\hline Timiş & $3000-3500$ & $6000-8000$ & 11000 & 12000 & 12000 \\
\hline Arad & $2500-3000$ & $7000-8000$ & 8500 & 9500 & 10000 \\
\hline Bihor & $2500-2800$ & $3000-3500$ & $4000-6000$ & $7000-8000$ & 9000 \\
\hline Ialomiţa & $2000-2400$ & $3000-4500$ & 5000 & 6000 & 7000 \\
\hline
\end{tabular}

Figure 2: The chart of price increase of agricultural land in the Western Plain of Romania Price: euro/ha

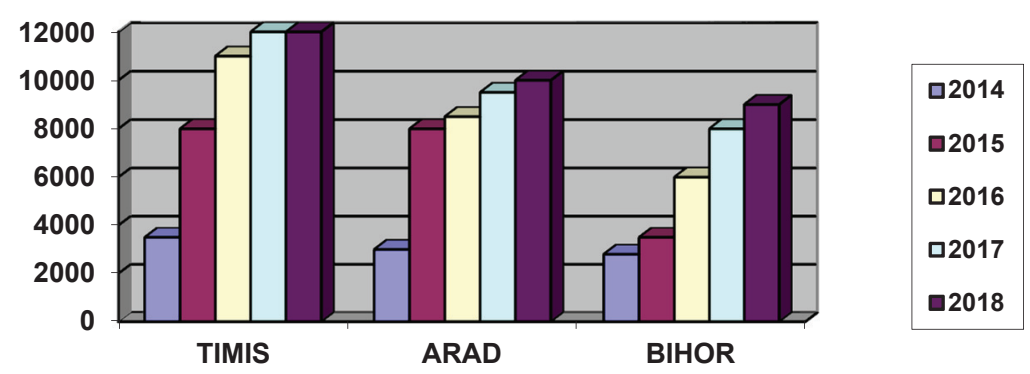

The price of agricultural land in Romania is still small compared to the land in Europe; in France the land is sold at prices between 8,000-25,000 euro/ha, in Germany between 25,000-33,000 euro/ha, in the Netherlands with prices between 25,000-60,000 euro/ha, Bulgaria between 4,000-8,000 euro/ha, and in Hungary between 6.000-11.000 euro/ha. In Slovakia, the land ranges between 8,000-12,900 euros/ha and in Italy between 15,000-100,000 euros / ha, according to Euro stat data.

According to the Ministry of Agriculture, in 2018, the most expensive land traded was:

\begin{tabular}{|c|c|c|c|}
\hline Arad County: & 32 ha & 537,000 euro & 16,800 euro/ha \\
\hline Timiş County: & 85 ha & 558,000 euro & 6,500 euro/ha \\
\hline Iaşi County: & 50 ha & 350,000 euro & 7,000 euro/ha \\
\hline
\end{tabular}

Buying farmland is more expensive than permanent pasture; the same for the irrigated land, as well as the mixed areas, were more expensive. The agricultural lands of Romania are very attractive for soil quality and proximity of the grain processing plants processers in Western Europe.

Foreign agencies specializing in land transactions say that foreign investors prefer this area for the superior productions than other European countries. The purchase of agricultural land has become an object of investment, not only an object of work for many investment funds on all continents. The investors say the land is of good quality, and the growing world demand for food makes it necessary to revive agricultural production.

\section{CONCLUSIONS}

In an increasingly globalized economy, capitalizing the economic potential of all regions is one of the fundamental objectives of sustainable development. It is imperative to respect geopolitical spaces and European policy to protect the specific areas. For Romania, a country 
with agricultural potential, it is imperative to develop a law that protects the land, encourages modern agriculture and protects local farmers. The example of European countries that condition their sales and protect their land fund must be followed. Agricultural land represents a strategic investment, and land is a means of production for an indefinite period.

\section{REFERENCES}

[1] Raport Comisia pentru Agricultură a U.E. (2015).

[2] Direcţii Judeţene pentru Agricultură - tranzacţionări terenuri agricole.

[3] Raport Transnaţional Institute Amsterdam (2015).

[4] www.agerpres.ro, 2016.

[5] Anuarul Statistic al României (2016).

[6] World Bank Development Indicators (2015).

[7] Revista „Capital”, aug. 2017.

[8] Eurostat - date statistice (2016).

[9] Black Sea Agriculture - terenuri agricole (2016). 